I 3 p. Ioo at the level of 20 p. Ioo pulps; the carcass quality was markedly improved (smaller fat depot).

In conclusion, it is not advisable to exceed $20 \mathrm{p}$. Ioo dried beet pulps in growing-finishing pig diets.

\title{
Utilization of some crude fibre rich raw materials in the feeding of bacon pigs : oat, wheat bran, dried beet pulp
}

\author{
J. P. BOUARD and M. LEULLLET \\ Institut technique des Céréales et des Fourrages, \\ 8. Avenue du Président Wilson, \\ 75116 Paris
}

In our experimental conditions, the best feed efficiency and the most favourable growth performances have been obtained with diets including highly energetic cereals (maize and wheat) combined with soybean oil-meal. However, in the absence of a rigorous feeding schedule and especially in the case of "pre-fattening", the carcasses obtained exhibited large amounts of subcutaneous depot fats and were penalized by the commercial grading.

Dilution of the energy concentration by bulk feeds has been studied in some trials and the results obtained show the impact of the source of crude fibre or type of cereal used in the diet : maize (MOAL, 1971), wheat (HENRY et BOURDON, I97I) or barley (HENRY et al., 1970).

As most of these trials were made under semi-ad libitum feeding conditions, it was decided to repeat them in true ad libitum feeding conditions (pre-fattening), using a classical crude fibre source (wheat bran) or a less traditional one (dried beet pulp and oat).

These two trials show that it is not advisable to use crude fibre, at least not under conditions of pre-fattening after $55 \mathrm{~kg}$ or ad libitum feeding during the whole fattening period. The attempts made to noticeably reduce the fatness of the carcasses did not succeed with the type of pigs available, and the feed intake increased.

\section{Energy value and utilization \\ of two types of barley (regular and hulless) by the growing-finishing pig}

\author{
Y. HENRY and D. BOURDON \\ Station de Recherches sur l'ílevage des Porcs, I. N. R. A., C. N. R. Z., \\ 78350 Jouy en Josas
}

In order to compare the utilization of two types of barley, regular and hulless, by the growingfinishing pig, two experiments were performed :

-- the first experiment was made on 2 groups of 7 castrated male pigs in metabolism crates, at an average body weight of $39 \mathrm{~kg}$, with the aim of measuring the digestible (DE) and corrected metabolisable (MF,n) energy values of the two types of barley in relation with the level of crude fibre. 
- the second experiment was conducted on 2 groups of 12 pigs in each (castrated males and females) with two pens per treatment. In these two treatments, the pigs were fed either regular or hulless barley from 30 to $\mathrm{r}$ oo $\mathrm{kg}$ liveweight, in the same feeding conditions with regard to energy-protein balance and energy level, which was differenciated according to sex in order to obtain lean carcasses.

From the digestibility trial, apparent digestibility of energy (ADIi) and nitrogen (ADN), DE and MEn values, in kcal per kg dry matter (DM) were respectively :

- for a regular barley (Winter variety Astrix) containing 7.21 p. Ioo crude fibre in DM : 79.4; $76.8 ; 3432$ and 3309 .

- for a hulless barley (a hybrid variety from INRA) with 2.80 p. Ioo crude fibre in DM: 86.4 ; $81.2 ; 3757$ and 3612 .

From these results we could establish a simple mean for predicting the DH or MEn value of barley according to its crude fibre content, on the basis of I.5 point decrease of ADE for I p. IOO increase of crude fibre in DM versus I p. Ioo for ADN. Thus, the DE value decreased by $70-80$ kcal for I p. Ioo increase in the crude fibre level in the fresh material ( $87 \mathrm{p}$. IOO DM). The MEn value may be obtained from DE after multiplying by the coefficient 0.96 . Evaluating the nutritional value of barley on this basis is perfectly founded since the two types of cereals (regular and hulless) were similar in the growth trial, when considering average daily gain, energy efficiency and carcass characteristics and for the same levels of energy and protein.

\title{
Performances of Large White pigs subjected to individual or paired feeding : variations related to sex and castration
}

\author{
J. M. PEREZ and B. DESMOULIN \\ Station de Recherches sur l'ílevage des Porcs, I. N. R. A., C. N. R. Z., \\ 78350 Jouy in Josas
}

The feeding trials performed at the experimental station are most frequently made with animals placed in indiviclual pens, as the feed intake and nutritive utilization of the diets can only be accurately determined under these conditions. However, it is reproached about this method that it changes the feeding behaviour of the animals. Therefore, in pig testing stations, two animals of the same sex are generally placed together in the same pen.

The purpose of the present experiment was to examine if the level and homogeneity of the performances are modified according to the fecding method (individual or paired feeding) in $a d$ libitum fed and separately kept male and female pigs.

The trial was made on 72 Large White pigs (entire males, castrated males, females) between I 8 and roo $\mathrm{kg}$ live weight. During the whole growth period, the animals received a single diet containing 15.3 p. Ioo crude protein and $3050 \mathrm{kcal}$ digestible energy.

The results obtained lead to two series of conclusions :

r. Under our experimental conditions, fattening and carcass traits taken as a whole were comparable for the two feeding methods (indiviclual or paired) : daily mean gain : $688 \mathrm{~g} / \mathrm{d}$; feed conversion ratio : 3.43 ; back fat thickness : $29 \mathrm{~mm}$. However, differences werenoticed, depending on the sex of the animals: in hogs the number of animals per pen clid not affect the performance criteria, whereas in boars, individual housing tended to increase the feed intake level. $(2 .+$ versus $2.2 \mathrm{~kg} / \mathrm{clay}$ ) and to a less extent, this was also the case for lemales (2.38 versus $2.25 \mathrm{~kg} / \mathrm{day})$. 